\title{
Får angst og depresjon etter abort
}

\author{
Mange kvinner får psykiske reaksjoner etter spontan eller provosert abort.
}

$\mathbf{T}$ all fra folkehelseinstituttet viser at det ble utført 15343 provoserte aborter i Norge i 2011, samtidig som 15 til 20 prosent av alle svangerskap ender med spontanabort. Hvis sykepleiere og helsepersonell informerer kvinnene om de ulike psykiske reaksjonene de kan få i ettertid av en abort, kan kvinnen bli mer rustet for hva som venter henne. Sykepleiere og helsepersonell generelt trenger derfor mer kunnskap og bør fokusere mer på de psykiske reaksjonene hos kvinner etter en abort, slik at kvinnene kan bli forberedt og mestre situasjonen på best mulig måte.

\section{Hovedbudskap}

Kvinner kan få psykiske reaksjoner i form av angst, depresjon, sorg, skyldfølelse og stress etter en spontanabort eller en provosert abort. Det er viktig at sykepleiere har kunnskap om at kvinner kan oppleve psykiske reaksjoner etter en abort, slik at kvinnene kan bli forberedt og mestre situasjonen på best mulig måte.

\section{Nøkkelord}

Les mer og finn litteraturhenvisninger på våre nettsider. ) Abort / Kvinne > Psykiskhelse Angst ) Depresejon

\footnotetext{
-
}

\section{Angst og depresjon}

Forskning viser at både spontanabort og provosert abort kan gi angst og depresjon. Hos kvinner med spontanabort var det sterkest etter ti dager, etter dette gikk angst og depresjon ned. Kvinner med provosert abort hadde mer angst på alle tidspunkter og var mer deprimerte både etter ti dager og seks måneder enn kvinner med spontanabort (2). Kvinner som har hatt spontanabort reagerer kraftigst den første tiden, mens kvinner med provosert abort har mer langvarige reaksjoner. Ved å sammenlikne skårene for angst og depresjon med normalbefolkningen viste det seg at kvinner med spontanabort hadde høyere skår enn normalbefolkningen etter ti dager, mens kvinner med provosert abort hadde betydelig høyere skår ved alle fire intervjutidspunktene (ti dager, seks måneder, to år og fem år etter aborten) (2). Kvinnene som var i tvil om beslutningen om å avbryte svangerskapet hadde betydelig større risiko for depresjon etter seks måneder (2). Dette viser at det er viktig at kvinnen har fått nok informasjon slik at hun (de) kan ta det valget som er best for henne. Kvinner som hadde en negativ holdning til provosert abort var assosiert med angst både etter seks måneder og fem år (2). Det viser at kvinner som har en negativ holdning til provosert abort kan være mer utsatte for psykiske reaksjoner i ettertid.
Det at kvinner får angst hvis de har en negativ holdning til abort, men likevel utfører det, viser at å ta et valg som går imot egne verdier kan påvirke deres psykiske helse. Kvinner som hadde en negativ holdning til provosert abort var assosiert med angst etter seks måneder og etter fem år (2).

\section{Sorg}

Forskning viser at kvinnene som tok spontanabort hadde betydelig mer følelse av tap og sorg etter ti dager og seks måneder enn kvinnene med provosert abort (2). Det ble også oftere observert sorg over tapet av barnet hos foreldrene som hadde hatt en spontanabort enn hos dem som hadde tatt provosert abort (7). Det at kvinner med spontanabort opplever sorg oftere enn kvinner med provosert abort kan ha en sammenheng med at kvinnene med spontanabort så på det som et tap, mens kvinner med provosert abort tok valget selv, og da oppfattes det ikke som et tap. Det at kvinnene opplever sorg etter spontanaborten kan være et uttrykk for at de var følelsesmessig bundet til barnet og at barnet var ønsket.

\section{Skyldfølelse}

Kvinnene med provosert abort følte betydelig mer lettelse enn kvinnene med spontan abort 


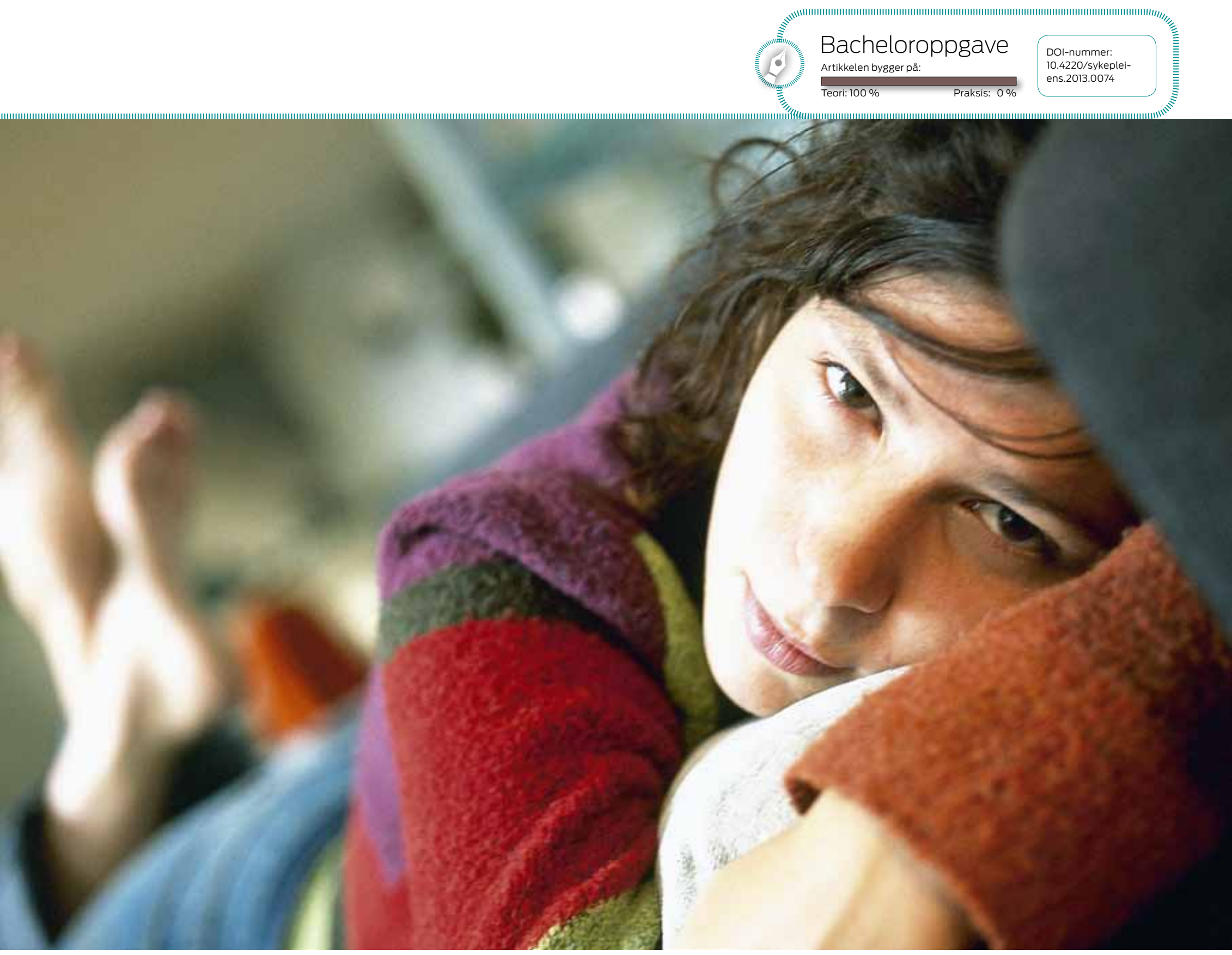

FÅR STRESS: Kvinner som tok provosert abort på tross av at dette stred imot deres verdisyn var ekstra utsatt for stress i etterkant. Illustrasjonsfoto: Colourbox.

ved alle intervjutidspunktene, samtidig hadde de også betydelig mer følelse av skyld og skam (2). Fergusson, Horwood og Boden (3) fant i sin studie at over 85 prosent av kvinnene som hadde tatt provosert abort hadde minst én psykisk reaksjon som tristhet, skyld, anger, sorg eller skuffelse. Dette viser at et stort antall kvinner får psykiske reaksjoner etter en provosert abort. De fleste av kvinnene som tar provosert abort ønsker ikke barnet, og opplever derfor ofte en lettelse etter aborten. Men provosert abort er fremdeles et tabubelagt tema. Det kan derfor være vanskelig for kvinnene å snakke om følelsene de har rundt valget og hvordan de har det i ettertid. Det at temaet er tabubelagt bidrar til at kvinnene kan føle skyld og skam for valget de har tatt. I studien fra Szymanska og Chazan prøvde over halvparten av kvinnene som hadde tatt provosert abort å finne en unnskyldning for valget sitt. Kvinnene hadde også lav selvfølelse etter aborten (7). Det at kvinnene prøver å finne en unnskyldning for et valg de har tatt er en ekstra belastning for dem. Noen kvinner som hadde tatt provosert abort fortalte at de kunne slå av fjernsynet hvis det kom et program som hadde noe med temaet graviditet og abort å gjøre, og at de vegret seg for å besøke venninner og søsken som nylig hadde fått barn (2). Noen kvinner opplevde en sterk følelse av å begå en dødssynd (7). Studien viser også at av kvinnene som hadde tatt provosert abort så nesten halvparten på fosteret som et uidentifisert skapning, mens alle kvinnene med spontan abort så på fosteret som et helt menneske (7). Hos kvinnene som hadde tatt provosert abort kan dette synet på fosteret skyldes forsvarsmekanismer som brukes til å rettferdiggjøre handlingen.

\section{Stress}

Forskning viser at kvinner opplever abort som en stressende livshendelse (6). Samtidig kommer det frem at abort kan være en måte å løse en stressende situasjon på og dermed også kan føre til lindring. Hvordan en kvinne opplever en abort og hvilken betydning dette får for hennes følelser i etterkant avhenger av hvordan hun

\section{«Provosert abort er frem- deles et tabubelagt tema.»}

reagerer og takler situasjonen. Studien viser at kvinner som tar abort oppfatter selve aborten og tiden etterpå som mer stressende hvis det å ta abort er i konflikt med hennes verdier.

\section{Forholdet til partner}

Studier viser at kvinner som hadde hatt spontanabort fortalte at forholdet til mannen ble påvirket ved at de ble mer «konsentrert rundt et ønske om å ha en annen baby», «snakket om fremtiden», og at «mannen ble mer gjennomtenkt» eller «følsom» (1). Det å miste et barn i 


\section{Det er mange fordeler ved å være sykepleier}

svangerskapets første uker kan utløse en krise i parforholdet, men det kan også føre til at partnerne kommer nærmere hverandre (5). Kvinnene som hadde hatt provosert abort fortalte at partnerens meninger og reaksjoner før og etter aborten betydde mye, slik at de ikke følte seg alene om valget. De fleste av kvinnene mente det var av stor betydning at de begge var enige $\mathrm{i}$ den endelige avgjørelsen og at de snakket åpent om den (1). Det at kvinnene og partneren hadde snakket sammen og åpent sagt hva de mente om valget betydde mye for kvinnene. Det at de ikke følte seg alene om valget har nok hatt stor betydning for kvinnenes psykiske helse i ettertid. De kvinnene som følte seg tvunget eller presset til å ta provosert abort, følte bitterhet og hat mot partneren. En av kvinnene som ble tvunget av sin ektemann til å ta provosert abort fortalte: «Jeg har et nag mot hele verden at jeg måtte gjøre dette, har ikke ord for det» (7).

\section{Konklusjon}

Kvinner som hadde hatt spontanabort reagerte i større grad med sorg og tapsfølelse enn kvinner som hadde tatt provosert abort. Imidlertid opplevde kvinner med provosert abort oftere skyldfølelse og skam. Alle kvinnene fikk angst og depresjon i ettertid. Hos kvinner med spontanabort gikk reaksjonene på angst og depresjon ned etter seks måneder, mens kvinner som hadde hatt provosert abort hadde mer langvarige reaksjoner. IIII

\section{REFERANSER}

Benute GR, Nomura RM, Pereira PP, Souza de Lucia MC, Zugaib M. Spountaneous and induced abortion: anxiety, depression and guilty, Rev Assoc Med Bras 2009; 55(3): 322-27.

2. Broen AN, Moum T, Bødtker AS, Ekeberg $\emptyset$. The course of mental health after miscarriage and induced abortion: a longitudinal, five-year follow-up study, BMC Medicine 2005; 3: doi. 1810267

3. Fergusson DM, Worwood LJ, Boden JM. Reactions to abortion and subsequent mental health, The British journal og psychiatry (BJP) 2009; 195: 420-26.

4. Folkehelseinstituttet (2012) Abort- faktaark med statistikk Tilgjengelig fra: http://www.fhi.no/eway/default.aspx?pid=233\&trg=Ma inLeft_6039\&MainArea_5661=6039:0:15,4576:1:0:0\%::0:0\&MainLe ft_6039=6041:70825:1:6043:1::0:0:0 (Lest 27. November 2012)

5. Flohr J, Wold K. Barnet som ikke ble-en bok om spontanabort, senabort og dødfødsel, Oslo: Emilia press AS, 2008.

6. Major B, mfl. Abortion and mental health. American Psychological Assosiation 2009; 9: 863-890.

7. Szymanska M, Chazan B. Differences between behaviours of female patients from Poland and Belarussia after natural miscarriage and induced abortion, Ethics \& Medicine 2008; (24) l: 29-39.

Fagartikler kan sendes til torhild.apall@sykepleien.no

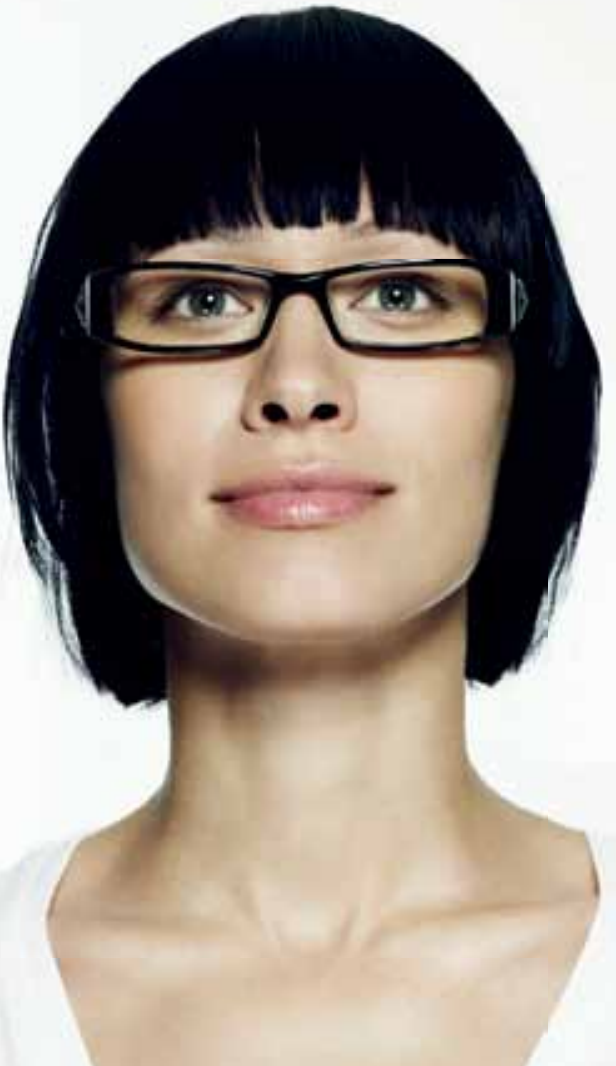

Norsk Sykepleieforbund har en avtale med Esso MasterCard - noe som betyr at du får fordeler andre bare kan drømme om:

* $50 \varnothing / /$ i drivstoffrabatt hos Esso

* $20 \%$ rabatt på bilvask hos Esso

* Inntil 2 familiekort til familiemedlemmer

* Ingen årsavgift eller gebyr ved kjøp

* Valgfri PIN-kode

\section{Søk om kort på:}

www.essomastercard.no/norsk-sykepleierforbund

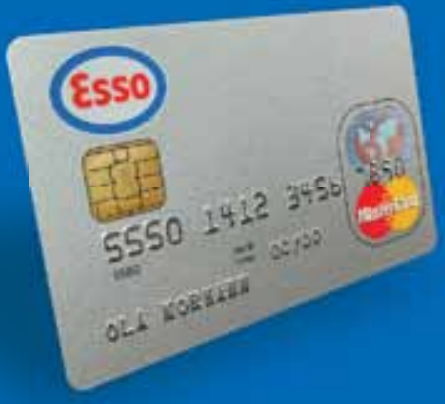

essomastercard.no

Drivstoffrabatt og mye, mye mer 